\title{
Ethical encounters in the archives
}

\section{On studying individuals in esoteric contexts}

https://doi.org/10.30674/scripta.85671

\section{MAARIT LESKELÄ-KÄRKI}

PEER-REVIEWED

www.tsv.fi/tunnus

$T$ his article discusses archival sources and biographical history in the context of the history of modern esotericism. Presenting as a case study, and the archival material of, a Finnish writer, Aarni Kouta (1884-1924), the article asks what are the ethical challenges that arise when studying individuals and their intimate sources in the context of esotericism? The starting point is in the forgotten figures of esoteric history, and thus the article reflects how our understanding of history, and more precisely on the history of esotericism, changes when we look at those whose history has not been presented before. I will argue that we need to be much more sensitive to the differences of the past when making interpretations concerning individuals, and we have to be ethically aware of our position as interpreters. This means careful working with historical source materials, but also sensitivity to both the long traditions of esotericism and to the multiple contexts of particular historical moments.

We encounter people from the past through the sources they have left behind, either by chance or because of a conscious effort to preserve. Either way, the sources we have are always partial and limited. A researcher interested in an individual life is always dependent on the material she has. Thus, the availability of sources has a strong influence on how we encounter people of the past. For example, a thorough, detailed life-long diary offers many more opportunities to analyse individual experiences than a collection of sporadic and fragmentary material that might include only few letters, some manuscripts, or notes.

The historian Jill Lepore (2013) had a very limited number of sources available when she started writing the biography of Jane Franklin, the unknown sister of the eighteenth-century politician, diplomat, mathematician and one of the founding fathers of the United States, Benjamin Franklin. In the context of this article, it is worth remembering that Franklin himself was involved in the wider esoteric movement as he was a freemason, 
became a grand master in $\mathrm{I} 734$, and as a printer published the first Masonic book in the Americas. In her research Lepore was not, however, interested in the life of Benjamin Franklin, but that of his sister, with whom he had a close relationship, although there are no remaining public documents to show that.

From a very scattered and fragmentary collection of source material, Lepore constructed a history of an eighteenth-century woman. Although exceptional, Jane Franklin's circumstances could be compared to the possibilities and conditions of many women of that particular historical era. Lepore's book reveals how what we can know of past lives is quite accidental. Throughout her book, she discusses how historians are bound by the randomness of history: 'History is what is written and can be found; what isn't saved is lost, sunken and rotten, eaten by earth' (Lepore 2013:6). Historical research is fundamentally bound to the materials that can be found, and in this article I will particularly pay attention to the encounters between these materials and a researcher as well as to the ways we can ethically approach the individual life-stories of people from the past.

Lepore's biography displays some recent trends, or even turns, in the field of academic biographical research. Women's agency, the gender perspective more generally, the perspective of the marginal and forgotten in history, as well as so-called relational biographies concerning couples, family members, friends or colleagues have become more and more popular (on new biographical research in the field of historical research, see e.g. Caine 2o Io; Halldórsdottir et al. 2016; Possing 20I 7; Leskelä-Kärki 20I 7). ${ }^{1}$ Although this article deals with a male protagonist, the Finnish writer and poet Aarni Kouta (I 884-I 924), the perspectives of the so-called 'new biography' come close, as the main character of my research is a forgotten, uncanonised writer, whose life ended prematurely and cannot be seen as typical for a biographical narrative that has concentrated more on the history of 'great' and 'important' people (see also Leskelä-Kärki 20 I6: I 88, 206).

The changes in biographical writing have also influenced the methodological discussions in the field of biographical research. This article is connected to these scholarly discussions as it discusses the practices of

1 In my previous research I have pointed out the hybrid aspect of the genre of biography, which demands careful methodological and theoretical tools and consciousness. For these discussions, see e.g. Leskelä-Kärki 20 I 7 . 
biographical research in a more specific context concerning the history of esotericism. This article draws on a similar kind of idea of the randomness in biographical research that Lepore above argues is a feature: as historians, we are bound to the fragmented material that is left from the past, and sometimes it is only coincidences that bring us together with the material. In this article, I will ask what happens when we encounter historical, archival material. Using the archival material of Aarni Kouta and his life narrative as an example, I will reflect upon how archival materials turn into research, and how a life lived turns into a biographical account.

My focus will be on the ethical challenges of studying individuals and their private sources in the context of esotericism. More generally, I will reflect ideas on biographical research related to individuals in esoteric contexts. I argue that we need to be much more sensitive to the differences in the past when doing interpretations concerning individuals, and we have to be ethically aware of our position as interpreters. This means careful working with historical source materials, but also sensitivity, both to the long traditions of esotericism and to the multiple contexts of particular historical moments.

\section{The individual and the otherness of the past}

As the research concerning esotericism has extended over the past decade into a very diverse field of study, from the study of religions into the fields of history, art, literature, music and popular culture studies, the approaches and theoretical perspectives have multiplied as well (see e.g. Harmainen and Leskelä-Kärki 20I7; Bauduin et al. 2018; Ferguson and Radford 20ı 8; Mahlamäki and Leskelä-Kärki 20ı8; Kokkinen 20r9; Kokkinen and Mahlamäki 2020; Faxneld 2020). Also popular literature has been active in presenting esoteric ideas, movements and individuals, but often in a way that has labelled people connected with esotericism as eccentric, or even immoral, pathological, and marginal (for Finnish examples see e.g. Häkkinen and Iitti 20I4). In our current research project, 'Seekers of the New' (see the project's website), our aim is to approach the cultural history of esotericism in Finland through the experiences of individuals, and seek for more solid, ethical ways of approaching esotericism in individual lives (Harmainen and Leskelä-Kärki 20 7; Mahlamäki and Leskelä-Kärki 20ı 8; Kokkinen and Mahlamäki 2020). 
As many scholars have argued, esotericism is a challenging concept that escapes strict definitions (Kokkinen 2019: 46-52; Kokkinen and Mahlamäki 2020: I 3-I6). For me, as a cultural historian, the scholarly context of modern western esotericism offers a new kind of perspective on the past, where it is possible to focus on the ways esoteric ideas, currents and movements have influenced culture and society. 'Esotericism' or 'esoteric' was not a concept used by contemporaries at the end of the nineteenth and early twentieth centuries. Rather, they talked about 'spirit matter', 'occult', 'secrecy', 'spirituality' etc. (see e.g. Owen 2004: 4-8, I 9-24; Leskelä-Kärki 2006: 248-58; Harmainen 2014; Kokkinen 201 9; Faxneld 2020).

In the context of this article, as in my research more generally, I approach the topic as a historian interested in the ways people of the past experienced the new esoteric movements of the late nineteenth and early twentieth centuries. I do not regard these movements or discussions concerning the occult and esoteric as something separate or marginal to society, but as a genuine part of the cultural and social discussions of the time. As Alexandra Owen in her groundbreaking historical study argues, occultism ${ }^{2}$ was not a shadow of modernity, but an essential part of the new worldview (Owen 2004: 4-8).

So far, our project 'Seekers of the New' has already shown how extensive and important the esoteric movements, ideas and thoughts have been in Finnish cultural history, in art, literature, in politics and in everyday life (see e.g. Kokkinen 20I9; Kokkinen and Mahlamäki 2020). As a scholarly concept esotericism opens up a new perspective onto the history that is already known; it reveals previously unknown corners and paths and imbues them with new meanings. Thus, a perspective of esotericism can change our perception of Finnish cultural history altogether. ${ }^{3}$

In the project, we are both seeking for the previously unknown people within the esoteric circles, as well as looking into the ways esotericism has

2 Owen published her work in 2004, and did not use the concept of 'esoteric' or 'esotericism'. The 'occult' and 'occultism' are general concepts that she uses to discuss 'the new spiritual movement' of the late nineteenth and early twentieth centuries, particularly Britain, but also in a wider European sense. She was one of the first historians to focus deeply on this field, and for a cultural historian her interpretations are very valid and influential.

3 In this regard, it is bit difficult to compare the situation of Finland to some other European countries, since so much more research has already been done elsewhere over the past twenty years, although that of modern western esotericism is still rather in its early stages. 
affected already famous historical figures that have been labelled 'great men' in the national history of Finland. ${ }^{4}$ However, it is not interesting only to look at those historical characters whose influence has already been acknowledged; the forgotten, marginalized or silenced figures are also of great importance, particularly in the context of esotericism. The forgotten ones in history have often been women, and in the context of Finnish research on esotericism this has been the case until recent scholarly works have started to raise awareness of women active in various esoteric movements (see Leskelä-Kärki 2006; Mahlamäki 20 т; see also Mahlamäki and Leskelä-Kärki 20ı 8). ${ }^{5}$

However, the forgetting does not only concern women, since there are many forgotten men as well. Their historical influence opens up in a different way in an esoteric context, and they may have been forgotten also exactly because of their esoteric views and actions. In an esoteric context, forgetting is often at least twofold: the esoteric interests of a person might have

This means for example painters of the golden era of national artists such as Akseli Gallen-Kallela, Hugo Simberg, and Pekka Halonen, whom Nina Kokkinen has been studying (Kokkinen 2019). Kokkinen's work has raised a lot of interest as these artists have been for the first time represented in the context of esotericism. Also many nationally important literary figures such as Eino Leino and J. H. Erkko are being studied in this context (see e.g. Harmainen 20 Io and 2014).

5 Internationally, feminist and gender studies have been interested in the field of esotericism, both in contemporary society and in history, and it has started to produce a vast amount of scholarly works (e.g. Owen I 989; Braude I989; Dixon 200I; Heidle and Snoek 2008; Kraft 2013). From a gender perspective, the history of esoteric movements is interesting since one of the biggest and influential movements, the Theosophical Society, was established by a woman and was also led for several decades by women. Spiritualism was led not only by men but also by women like Emma Hardinge Britten, and women were active as mediums and as performers during the late nineteenth century (see more in Braude I988; Owen I989; Kaartinen and Leskelä-Kärki 2020). However, women's agency has not been acknowledged in the earlier Finnish writings concerning esoteric movements. Even the most recent popular fact book Valonkantajat neglects the influence of women. The list of characters has only a handful of women, and of those only four are women who have been active agents in some esoteric form of movement. Valonkantajat (Häkkinen and Iitti 2015) has been a pioneering book covering the previously unwritten history, and as such it discusses the common distortion in the perspective: once we start covering something new, the men are important, and it is only a secondary consideration whether women have also been active. 
been marginalized or 'forgotten' in earlier studies and/or historical sources (see e.g. Kaartinen 2018), or their esotericism might have been a cause for neglecting the influence of a person in a broader cultural context.

Individuals can thus act as meaningful agents whose experiences and actions open up the previously undetected scene of esotericism in Finnish cultural history. Interpreting individuals in their social and cultural context allows us to both see what is different in particular historical spaces, and to recognize the familiar that travels across historical times and circumstances. Thus, an esoteric perspective might turn the previously known cultural history upside down, as it reveals hidden meanings, hidden actions and hidden figures.

A historian is always faced with otherness and strangeness. Discussing the perspective of cultural history, Professor of English Bruce Johnson refers to a citation from L. P. Hartley's I 953 novel The Go-Between: 'The past is a foreign country; they do things differently there'. The latter sentence reminds us, as Johnson puts it:

...that the past is indeed heard as distant echoes of both itself, and of those who have engaged with it as historians. The past can never directly represent itself to us, but, in the word of another writer seeking illumination, is perceived 'through a glass darkly'.

Johnson points out the crucial idea of the presence of history, and its ever-changing nature by continuing as follows:

The past is present in two senses: that our history never leaves us, never relinquishes its hold over our sense of what is possible now and in the future, and it is present in the sense that the past is still in flux through acts of memory: it has not finished its doing. (Johnson $20 \mathrm{II}$ : I-2)

To say this in other words; history is always present and changing in one particular historical moment.

These words seem especially fitting when discussing the history of esotericism, and the ways we could study those individuals who became interested in various esoteric currents. The questions that arise from the currently flourishing research tradition of modern western esotericism open up history in a new way - we recognize things we haven't recognized before, and we are able to connect them to a larger, transnational history of esoteric 
currents, movements and ideas. All the research done at the present time changes our view on history, and also allows us to write new chapters, in this case, in the cultural history of Finland.

\section{A forgotten man in the archives}

Approximately two years ago our project 'Seekers of the New' received a call from a descendant of the Finnish poet Aarni Kouta. She had heard about our project on a radio programme (Häkkinen 20I6). The outcome of this phone call was the receipt by us of several cardboard boxes full of Aarni Kouta's personal material. These included his published books and manuscripts, his writings, some collections of the theosophical journal Tietäjä, as well as the Ruusu-Risti journal, a few hundred letters, notes, writings of his, and, what is most interesting, tens and tens of photographs and glass negatives. At that time, Kouta was, for all of us in the project, unknown; no more than a distantly familiar name related to the early twentieth-century literary

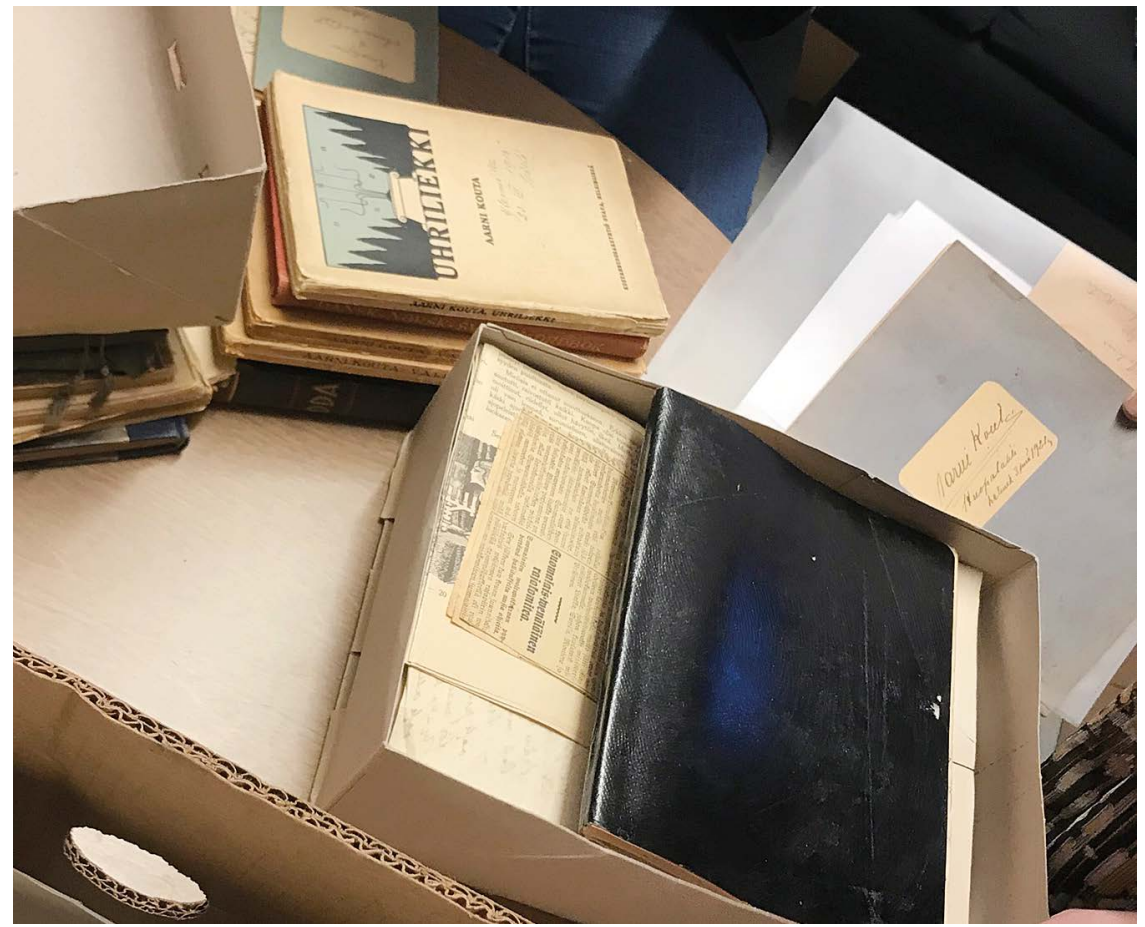

The archival material of Aarni Kouta was donated to the research project 'Seekers of the New' in 2019. Archives of Aarni Kouta (AAK). Photo by Maarit Leskelä-Kärki. 
poetic scene. However, as we became familiar with the material, it became evident that Aarni Kouta would become one of the important esoteric persons in our project and its future publications.

Kouta represents an interesting figure in the context of Finnish esotericism. Besides his (mainly forgotten) literary activities as a poet and translator, he was quite deeply involved with the theosophical movement and those close to the society, especially Pekka Ervast, the founder of Theosophical Society in Finland. Aarni Kouta's material opens up a new perspective on the tradition of Finnish esoteric literature, as well as on the influence of esotericism in the small literary circles of Finland in the early years of the I goos. The position of Aarni Kouta is, in a way, twofold: a forgotten writer in the context of a forgotten esotericism in the cultural history of Finland. I argue that by studying his life story and the materials in his archive it is possible to add new dimensions to the connections between literature and esoteric currents in Finland during the early twentieth century; and also to reveal some reasons behind this cultural forgetting.

Arnold Elias Candolin was born near Hämeenlinna in September I 884, and was the son of a vicar. From early on he seems to have directed his passion towards writing and literature. Attending upper secondary school in Porvoo, a small town near Helsinki, in the early i goos, he had already started reading Nietzsche and became one of those writers whose work and ambitions were connected to Nietzschean philosophy and ideals. In Esko Ervasti's study from I 960 he is one of the Nietzschean writers in Finnish literary history of the early i goos together with, for example, Joel Lehtonen, Volter Kilpi, Eino Leino and L. Onerva, who were all also close friends of Kouta. Already at the age of $\mathrm{I} 7$, he started translating Also sprach Zarathustra. This was finished in 1907, and thus became the first translation of Nietzsche in Finland. Later he translated The Antichrist in 1909 and a collection of his poetry. Aarni Kouta was himself mostly a poet, and he published altogether eight poetry collections as well as some prose works. Aside from that he worked as a translator and was an active writer in newspapers and particularly esoteric journals. ${ }^{6}$ In the following, I will look at Kouta's archival remains from three perspectives.

6 Facts and details of Kouta's life are collected from various sources, particularly from Ervasti i 96o; Saurama, AKK; 'Aarni Kouta - runoilijakuva', AKK; Kortelainen 2006; Tarkka 2009. 
Firstly, in the archival material Kouta is represented in a very specific way, since a great proportion of the material consists of photographs and photo albums mostly taken and collected by his second partner Elsa Roschier, who was an enthusiastic amateur photographer. The material consists of hundreds of photographs and albums, most of them taken by Elsa, but also by Aarni. Their family life can be followed from the albums, since she photographed their home, their family life, summer places and Helsinki city life in the early i goos. The couple had two sons who were born around I9Io. The photographs open up a rare and immensely valuable perspective into their life and also their networks, since there are many photos also of their friends; Finnish writers and artists of that time such as L. Onerva and Eino Leino, Juhani Aho, Akseli Gallen-Kallela, Toivo and Alma Kuula and Wilho Sjöström. The photographs show in a very concrete and material way how people are connected to other people, and how lives are relational. Kouta's life opens up in the various relations that his archive reveals. Kouta's literary work and his networks open up a perspective on his surroundings, on those people he networked with. This way it is possible to find new interpretations and new facts on the meaning of esoteric movements, ideas and undercurrents. An individual opens up a larger perspective than on himself only. ${ }^{7}$

Secondly, the archives show how Kouta's esoteric activity is connected to both theosophy and the Rosicrucian movement which Pekka Ervast established in 1920. There are several copies of the Tietäjä and RuusuRisti journals as well as some letters from, for example, Pekka Ervasti. No extensive correspondences have been preserved, though. It is as yet somewhat unknown how exactly Kouta got to know Pekka Ervast, the founder of Theosophical Society in 1907, and later, the founder of the Rosicrucian Order (Ruusu-Risti) in Finland in I 920. But previous research has already acknowledged Eino Leino's deep interest in theosophy and his friendship with Pekka Ervast, so it seems obvious that Kouta was involved in the same circles in Helsinki. ${ }^{8}$ Kouta's works are to be found at least in the numbers of the Tietäjä journal published by the Finnish Theosophical Society in the late I 9 Ios and then in the early I920s in the journal Ruusu-Risti published

7 On relationality in life writing, see Leskelä-Kärki 20I6: I 9I-3. On relationality in group biography, see e.g. Hakosalo 2016 and Harmainen 2016. 


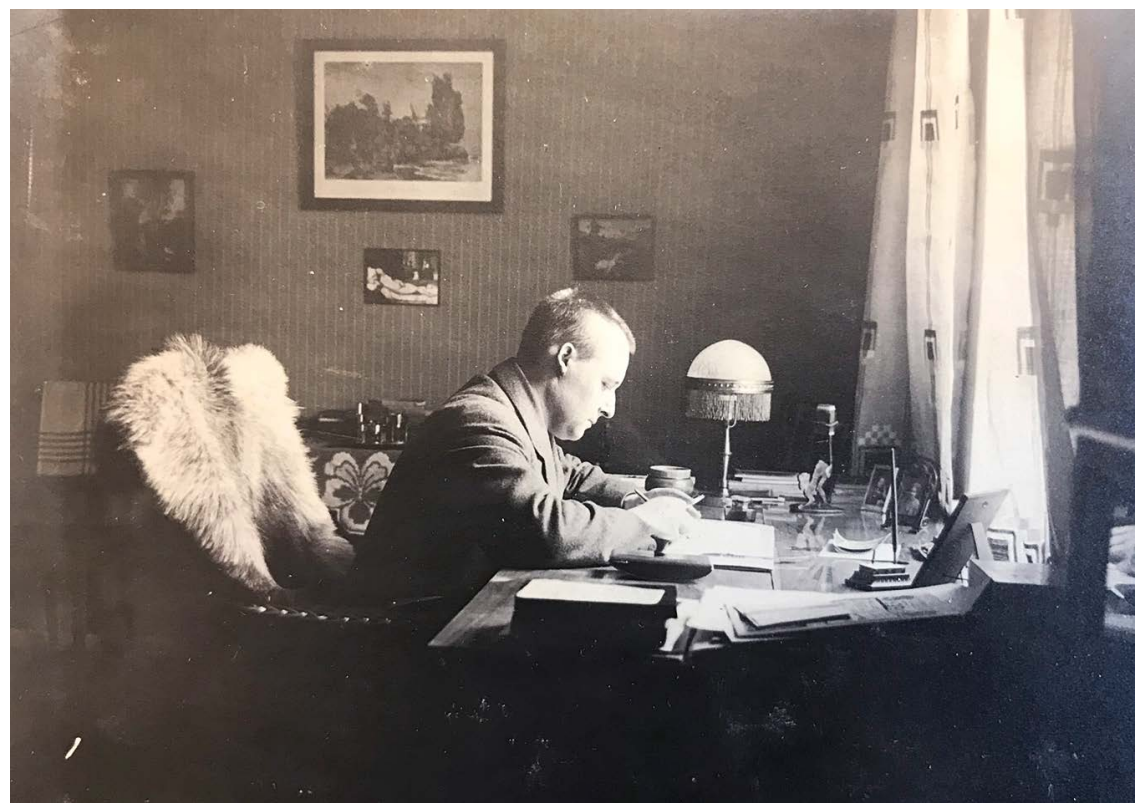

Aarni Kouta by his desk, c. 1910. Photo by Elsa Roschier. Archives of Aarni Kouta (AAK).

by the Ruusu-Risti society. ${ }^{9}$ The decision of Pekka Ervast to establish a new kind of movement and take some distance from theosophy can be seen as a way to connect the movement more deeply to the Finnish context and Western culture at a time when the international theosophical movement turned more and more towards Hinduism and Asian culture. The connections to Christian culture were more in the focus in Ruusu-Risti. The movement stands for the idea of rebirth and the law of karma. In Ervast's idea the movement of Ruusu-Risti is what Blavatskian theosophy was in its purest form (Laine and Kokkinen 2020). In its rules the Ruusu-Risti society declares that it is the temple of free thought, whose members seek the core of truth, the secret godly wisdom, that is hidden in all religions, mythologies, philosophical and scientific systems (the rules of Ruusu-Risti, AAK). Kouta was a contributor to Ruusu-Risti journal, but documentation on his other activities in the society is so far lacking.

9 Here I prefer to use the Finnish Ruusu-Risti, since the version Ervast established is niether related to the earlier international Rosicrucian movement, nor to The Salon de la Rose+Croix. Ervast's decision to establish a new society tells more about the inner contradictions in the Theosophical Society. 
Thirdly, besides social networks and his activities in esoteric movements, the Kouta archives reveal more delicate and ethically difficult information. From various sources it can be deduced that Kouta suffered from mental unbalance, probably depression, and most of all he seems to have been a drug addict using morphine. Kouta was admitted to a mental asylum in Kivelä in I9I 7 suffering from anaemia, depression and anxiety - his brother had said that he had been using morphine and cocaine for many years. This fact is recorded in a book portraying the history of drug use in Finland, and Kouta is there by mention of his initials only (Ylikangas 2009). It can also be verified from a biographical account that Kouta's brother wrote after his death, and that is still available among Kouta's personal archives ('Aarni Kouta - Runoilijakuva', AAK).

In Kouta's case, his mental condition is quite significant, since he committed suicide in 1924 . Just before his death he published a poetry collection called Aurinkobäät (Sun Wedding). In the manuscript there is a dedication to Elsa that says 'to Elsa, my only one, who has given me everything that has been and is worth living for' (Aurinkohäät, AAK). Kouta's archive also consists of tens of letters exchanged between the spouses, including the years they were no longer living together (approximately from I9I4 onwards). Kouta's letters from his last years in the I 920 provide especially challenging material for a scholar. The letters are long and contemplate his feelings for Elsa and his longing for her. The most challenging document is his last letter to her. Kouta started to write a letter to Elsa at the point he had decided to take a mortal dose of veronal; later his brother mentions that it took three days for him to die ('Aarni Kouta - Runoilijakuva', AAK). The letter has a handwritten message on the cover saying that it should be given to Elsa after his death, and it is surrounded by a black line, that reveals it is a mourning letter of some kind. In this article, my focus is not on the content of this letter; rather, it stands for the ethical challenges of this particular biographical case. This letter, or Kouta's mental health, is not to be separated from an analysis of Kouta's esoteric life, since his personality, literary identity and worldview are deeply interwoven.

Kouta's fragmentary archive opens up the challenges of biographical research. It consists mainly of the material he himself has kept, and after his death it has probably been saved by his brother, possibly also by Elsa and later on by some of his children. Apart from these materials, we can find information about Kouta from various biographies concerning his close colleagues and friends. The biographies of Eino Leino, Joel Lehtonen and 
L. Onerva (e.g. Tarkka 2009; Kortelainen 2006; Rajala 2018) tell incidental stories, for example, of his trip to Rome in 1908 together with Leino, Onerva and Lehtonen, or their co-operation on the journal Sunnuntai in the late I 9 Ios. Yet we have to ask; how are we able to construct life narratives according to scattered sources that are often quite randomly saved? What can all this material reveal of Aarni Kouta as a poet, as an esoteric person, and of his position in the cultural history of Finnish literature and writing? Does all this give some answers as to how he came to be forgotten? And what does forgetting even mean? So in the end, the researcher stands alone with the material of Kouta, sees him and his wife Elsa in pictures, and wonders how to approach his life story.

Kouta's archives could be approached from several perspectives. He could be viewed against the context of literary history in Finland, and as one of the young, prominent writers of the early r goos who were interested in philosophical and symbolist approaches particularly related to Nietzsche. There he is among the most distinguished and canonized writers such as Eino Leino and Volter Kilpi. Another perspective, that could be added to

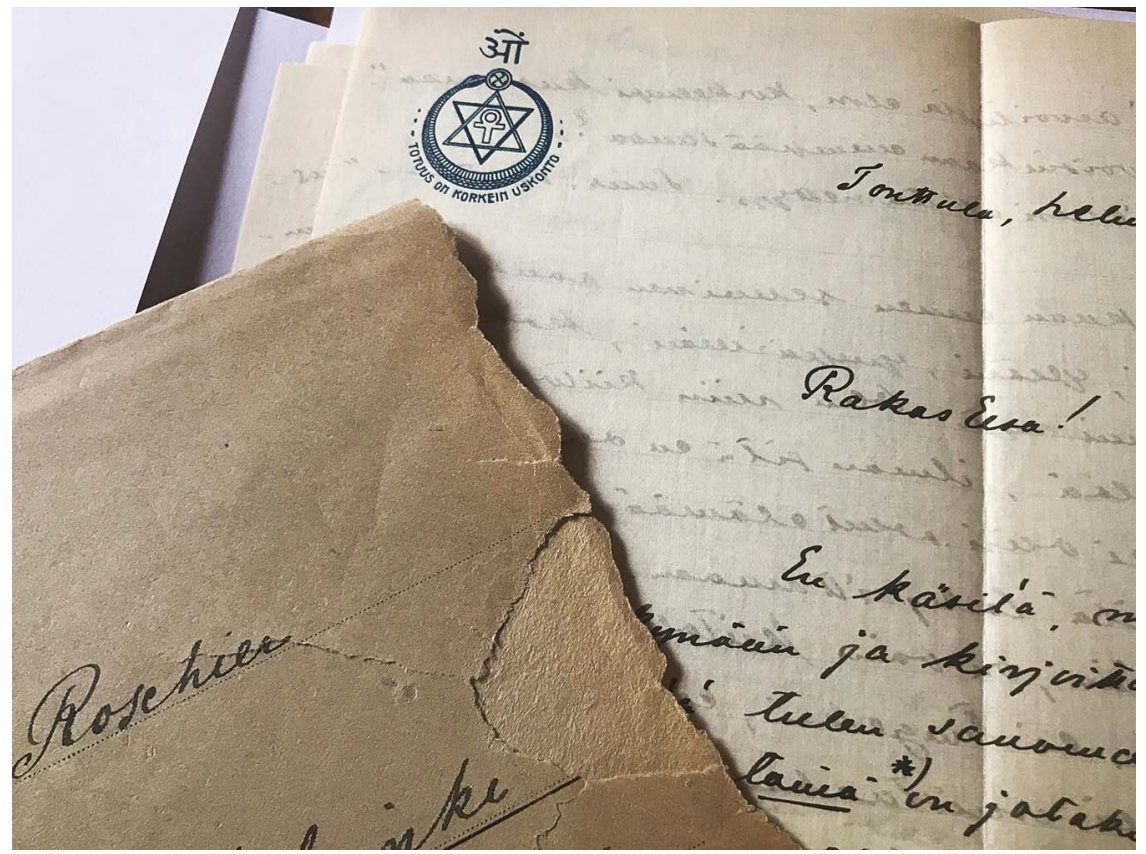

Aarni Kouta's letter to his wife Elsa Roschier in 1919, written on the headed paper of the Finnish Theosophical Society. Archives of Aarni Kouta (AAK). Photo by Maarit LeskeläKärki. 
the previous one, is a gender perspective. How could Kouta's somewhat unstable, addictive personality be analysed in the context of manhood and various gender discussions of the early i goos? And, last but not least, how could Kouta's life story and archives help to open up the hidden history of esotericism and esoteric movements in Finnish cultural history?

From a biographical viewpoint the international history of modern esotericism has been written from the perspective of leaders, influential figures and prestigious esotericists. This is, of course, not a surprising fact, since biography has until recently been dedicated mostly to the 'grand' figures of history (statesmen, kings and queens, famous artists and writers, politicians etc.). However, over the past three decades the focus has changed, mostly due to an overall change in history writing. This change has mostly been affected by women's history, the history of everyday life, and marginal histories. This turn has had a huge influence also on biographical writing. Particularly from the early 2000 s we can see a flow of biographical works related to forgotten persons or marginal figures, as well as various methodological means of approaching historical lives (about the more general change, see e.g. Caine 2009; Halldórsdottir et al. 2016; Possing 201 7 ).

The field of biography in the modern history of esotericism covers such names as Helena Petrovna Blavatsky, Annie Besant, Rudolf Steiner, G. I. Gurdjieff and Aleister Crowley, about whom already tens and tens of biographies and biographical accounts have been written. The biographical literature related to the history of esotericism can be seen as many sided; there are, for example, the popular, yet research-based biographies of well-known figures written, for example, by Gary Lachman ${ }^{10}$. The more scholarly biographical books tend to have a certain perspective or thematic angle when studying individuals (e.g. Pasi 2014) and then there's, obviously, the long tradition of writing traditional biographies on leading figures of esoteric movements. Research on esotericism covers also those biographical accounts where the writer has a reverent relationship to his or her subject - these are written mainly inside the esoteric movements. All these various biographical types can be seen in parallel with biographical writing in in general.

The field of biographical writing seems to hold quite a firm hand on traditional ways of recounting the life of important esoteric men and women. It

10 He has written biographies on, for example, Helena Blavatsky, Rudolf Steiner, Emanuel Swedenborg, Carl Gustav Jung. 
has not been interested in the 'ordinary' participants or marginal figures of the movement, or on a more relational perspective towards esoteric persons. The case of Aarni Kouta opens up a different kind of perspective, and the particular nature of his archive allows us also to ponder various ethical challenges. Some of them are particularly related to the study of the history of esoteric persons; however, many of these challenges are more general, and valid for all biographical research. In the following, I will raise some of these issues and discuss the ethics of this particular biographical case study.

\section{Empathy as an ethical standpoint}

In recounting Kouta's life according to his remaining material, it seems I have already constructed a certain narrative of his life. I have contextualized Kouta with the idea of the marginal and forgotten in the history of Finnish esotericism, brought up his close networks with more canonized writers, pointed out his connections with theosophy and Ruusu-Risti, as well as dwelt on the misery of his life. One has to ask, how will his life narrative be constructed in my future research? What kind of story of Finnish esotericism will it illuminate?

These considerations force one to encounter necessary ethical questions that we are faced with when dealing with individuals from the past and their autobiographical material. Writing a biography is a dialogical process in which the writer constantly mirrors his or her interpretations in relation to the other, the subject of the biography. As biographers, we thus become deeply involved with the past lives - we become interpreters, actors, close bystanders, who also come to be affected by the stories we read and by the interpretations we construct. In my previous research I have argued that we need to pay attention to these emotions, attachments and detachments, and in doing this, I have proposed empathy as a conceptual tool (Leskelä-Kärki 2006: 83-5; Leskelä-Kärki 20 I 4; Halldórsdottir et al. 2016: 25).

As the word 'empathy' comes from the Greek words em pathos ('to feel inside'), that means an ability to put oneself into other person's position and to understand how the other feels. Empathy is thus not the same as compassion (sym pathos, 'to feel together'), since empathy means more the inner understanding of a person. Empathy could be seen as a statement; admitting the presence of a researcher and the reflexivity that a biographical research demands. Empathy could work as a concept to point out the meaning of the position of a researcher - thus it does not mean that a biographer would try 
to experience something together with his or her protagonists, or identify with them. Rather, it means also taking a critical distance towards them, to ask questions from them, to be visibly present in the research, and to recognize one's position (Leskelä-Kärki 2006: 78-85, 636; Leskelä-Kärki 20I4).

From this perspective, empathy can be regarded as an essential part of the research process, where every phase is important, from the very first moments spent in the archives, in the midst of the various, fragmentary materials dealt with, up until the process of writing, gathering information, and making interpretations. Empathy requires slowness; slow moments with your sources, days and weeks in the archives. ${ }^{11}$ When working with material such as Aarni Kouta's archive, this slowness proved to be a point of departure for an ethical approach. For me, Kouta was an unknown figure whose poetry I had not read, whose life story I did not know, and whose impact on the cultural history of Finland was hidden. Thus, going through his archives, reading his letters, trying to make sense of his messy handwriting and confusing emotions, seeing his manuscripts, looking at him in the photographs, looking and reading the fragments of his life at a slow pace has been of utmost importance in order to start seeing him in a larger cultural context. Consequently, I have paid attention to those moments and fragments that I regard as valuable perspectives to his life - another scholar would see something different in these same archives.

This is what empathy is about: seeing and recognizing valuable moments during the research process. Empathy works through imagination. One cannot be empathetic without an ability to imagine. On the basis of various materials and historical facts we have to be able to imagine the person from the past, and his life. And in this we also need an ability to carefully contextualize the surroundings of such people. Consequently, we could conclude, that the key to understanding people from the past is in the historical context. Here context refers to the broad understanding we are able to attain from the historical and social context of an individual. In this we have to be sensitive to historical differences as well. With this kind of careful contextualisation, we could use empathy as a possible way to make individuals from the past understandable.

The empathetic approach allows us to see the past life story not as a final conclusion but as a process and interpretation, a possible narrative 
seen and written from one possible perspective, as a possibility, not as a concluding final narrative. ${ }^{12}$ The cultural historian Jukka Sarjala (20 I4) has discussed the concept of 'an endless individual', who does not empty itself into one context, but is on the move constantly. For Sarjala, the question of the changing nature of an individual is fundamental. A human being is all the time on the move towards various directions, and he or she does not fit coherently into one particular context. Thus, we have to be able to imagine people from the past as endlessly changing, and be sensitive to the wide variety of contexts of particular historical moments.

In the context of the history of esotericism the idea of an endless individual could prove to be a valuable point. Since the whole concept of esotericism is quite obscure, the idea of endlessness seems appropriate particularly when we study people from the past in this context. Often esotericism offers only one possible context for an individual, since only some have clearly stated their esoteric context, for example by being a member of some movement. When discussing artists and writers it is more common that their connections to esoteric movements are quite unclear. Thus, the importance of esoteric contexts varies, and it seems, that, for example, in the case of Aarni Kouta, we would have to analyse his writings in great depth in order to thoroughly examine the meanings of the occult and the esoteric in his life. This demands also a close reading of his various connections to various literary contexts and relationships at different times of his life. The esoteric and the occult offers one possible, and in itself also an endless, context for his life.

Kouta represents a case where silence and forgetting play a major part. His case shows on a micro level how cultural memory is constructed. He was part of the most important and flourishing group of young artists and writers, published many poetry collections and also translated some of the most influential literature of his time. His life story seems to be that of a seeker; he attached himself to many other literary figures and seems to have been searching for the inner understanding of life and humanity. ${ }^{13}$ Nonetheless, Kouta has been on the margins of Finnish literary history. Of course, his career was not a long one, and also his drug abuse and suicide must have affected his cultural position, but still there remains the question as to whether his esotericism has somehow influenced this marginal position. It

12 About the idea of possibility in cultural history, see e.g. Salmi 20 Io.

13 On seekership, see Kokkinen 20 I 9: 52-66. 


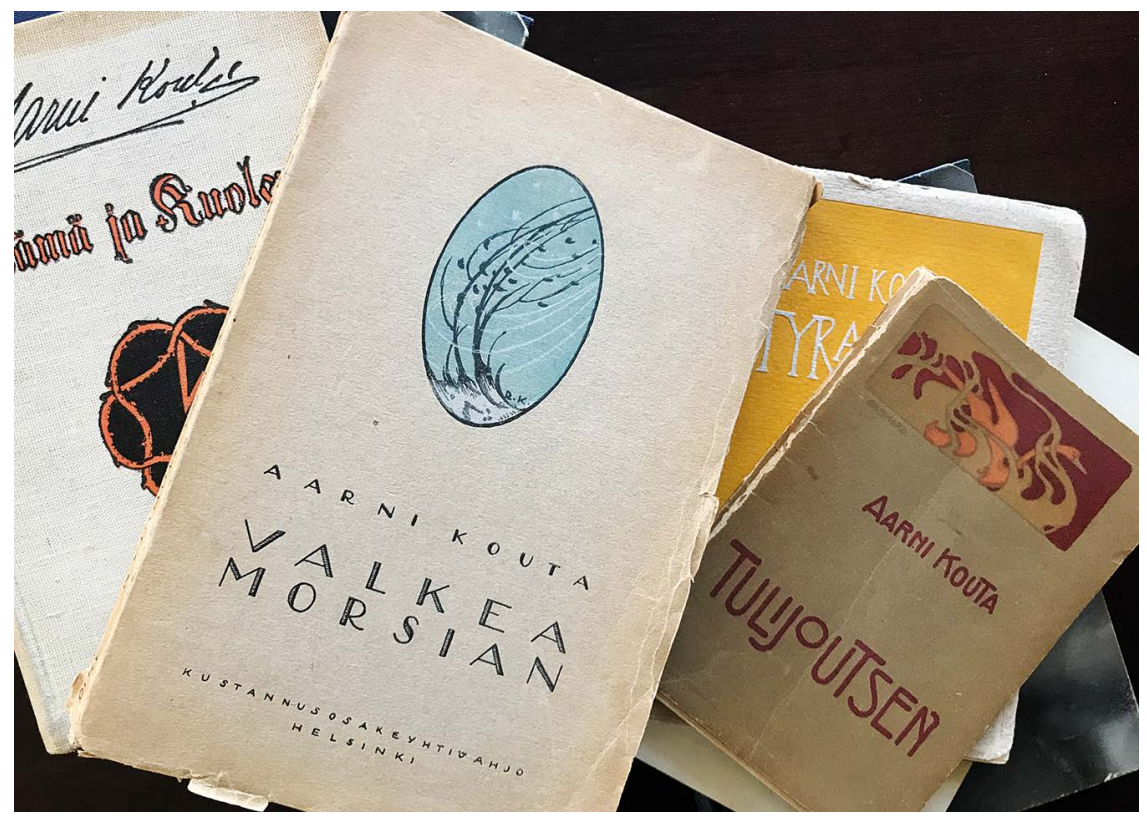

The body of Aarni Kouta's literary work consists primarily of eight collections of poems. Archives of Aarni Kouta (AAK). Photo by Maarit Leskelä-Kärki. s

seems that Kouta's material and his life story can offer diverse perspectives and possibilities in constructing interpretations, where the importance of esoteric ideas, currents and networks would be more visible and valued.

Aarni Kouta's life story, and the material he has left behind, leads a researcher to ponder how we constitute one person's life, and what we can, ultimately, know about past lives. How does biographical knowledge come into being, and how accidental is this knowledge, in the end? Asking these questions, we seem to be at the core of humanity and life: What is life? What is humanity? What is an individual's part in larger historical currents? These questions were also asked by theosophists, spiritualists, anthroposophists, rosicrucians, and others attracted to new esoteric ideas and movements of the early twentieth century. For a biographer, these questions must always be at the core of our research. In the case of Aarni Kouta the questions related to his life remain to be answered, but to conclude this article, it is important to hear his own voice; how he saw life and a human being's part in it. In an extract from his poem 'Katoavaisuuden kuoro' (A Choir of the Perishable) Kouta sees life as follows: 
What is life?

A light golden ribbon of the Moon Goddess,

That joins together earth and heaven,

Bridge between night and the sun.

What is life?

The silver rain of the daylight,

That tenderly falls on the troubles of Man. ${ }^{14}$

(Kouta I9I I: 34)

Maarit Leskelä-Kärki (PhD, Adjunct Professor) works as a Senior Lecturer at the Department of Cultural History at the University of Turku. She is also the vice-director of SELMA: Centre for the Study of Storytelling, Experientiality and Memory, and the Director of the research project 'Seekers of the New' (2018-20). Her main research interests include life-writing studies, the cultural history of writing, gender history and cultural history of modern western esotericism. She has written for example on epistolary and diary practices (e.g. edited anthology Päiväkirjojen jäljillä. Historiantutkimus ja omasta elämästä kirjoittaminen, Vastapaino 2020), biographical research (e.g. edited volume Biography, Gender and History: Nordic Perspectives, k\&h-kustannus 2016; Toisten elämät. Kirjoituksia elämäkerroista, Avain 2017) and on women in spiritualism (in the anthology Moderni esoteerisuus ja okkultismi Suomessa, Vastapaino 2020).

\section{References}

Archival sources

Archives of Aarni Kouta, The Archives of the School of History, Culture, and Arts Studies, University of Turku (AAK)

'Aarni Kouta - Runoilijakuva'

Kouta, Aarni: Aurinkohäät, manuscript

Saurama, Anna: Notes on the personal history and family history of Aarni Kouta, information sent as document to the author

Literature and other sources

Bauduin, Tessel M., and Henrik Johnsson (eds.), 201 8. The Occult in Modernist Art, Literature, and Cinema (London, Palgrave Macmillan)

14 'Mitä elämä on? / Kevyt Kuuttaren kultarihma, / mi liittää yhtehen maan ja taivaan, / välisilta yön sekä auringon. / Mitä elämä on? / Päivänpaistehen hopeavihma, / mi lankee lempeenä ihmisen vaivaan.' (Translation into English Maarit Leskelä-Kärki and Kimi Kärki) 
Braude, Anne, I989. Radical Spirits: Spiritualism and Women's Rights in Nineteenthcentury America (Boston, Beacon Press)

Caine, Barbara, 2o го. Biography and History (Basingstoke, Palgrave and Macmillan)

Dixon, Joy, 200 r. Divine Feminine: Theosophy and Feminism in England (Baltimore, Johns Hopkins University Press)

Ervasti, Esko, I 960. Suomalainen kirjallisuus ja Nietzsche, vol. I. 1900-luvun vaibde ja siihen välittömästi liittyvät ilmiöt (Turku, Turun yliopisto)

Faxneld, Per, 2020. Det ockulta sekelskiftet: esoteriska strömningar i Hilma af Klints tid (Stockholm, Volante)

Ferguson, Christine, and A. Radford (eds.), 20 I 8. The Occult Imagination in Britain, 1875-1947 (Oxford, Routledge)

Häkkinen, Perttu, 20 I6.' Esoterian vaikutus suomalaiseen kulttuuriin', Yle Areena, 3.5.20I6, <https://areena.yle.fi/I-34I9868>

Häkkinen, Perttu, and Vesa Iitti, 20 I 5. Valonkantajat. Välähdyksiä suomalaisesta salatieteestä (Helsinki, Like)

Hakosalo, Heini, 20r6. 'Coming together: early Finnish medical women and the multiple levels of historical biography', in Biography, Gender and History: Nordic Perspectives, eds. Erla Hulda Halldórsdottir, Tiina Kinnunen, Maarit Leskelä-Kärki and Birgitte Possing (Turku, k\&h-kustannus), pp. 209-30

Halldórsdottir, Erla Hulda, Tiina Kinnunen, and Maarit Leskelä-Kärki, 20 ı 6. 'Doing biography', in Biography, Gender and History: Nordic Perspectives, eds. Erla Hulda Halldórsdottir, Tiina Kinnunen, Maarit Leskelä-Kärki and Birgitte Possing (Turku, k\&h-kustannus), pp. 7-35

Harmainen, Antti, 2oro. Modernin mystikot. Teosofian ulottuvuudet Pekka Ervastin ja Eino Leinon maailmankuvissa 1902-1908, MA diss. (Tampere, Tampereen yliopisto), <http://urn.fi/urn:nbn:fi:uta- I-207 Io>

20I 4. “"Kaikki voin kestää, voin elää, jos tiedän että hänet kerran vielä tapaan”. Spiritualismi ja teosofia sivistyneistön surutyön välineinä I 880luvun lopulla', Historiallinen Aikakauskirja, 4, pp. 382-92

2016. 'Group biography as an approach to studying manhood and religion in late nineteenth-century Finland', in Biography, Gender and History: Nordic Perspectives, eds. Erla Hulda Halldórsdottir, Tiina Kinnunen, Maarit Leskelä-Kärki and Birgitte Possing (Turku, k\&h-kustannus), pp. Iо I-20

2020. 'Teosofia', in Moderni esoteerisuus ja okkultismi Suomessa, eds. Tiina Mahlamäki and Nina Kokkinen (Tampere, Vastapaino), pp. 9 I-I I I

Harmainen, Antti, and Maarit Leskelä-Kärki, 20 I 7. 'Moderni länsimainen esoteria historiallisena ilmiönä ja tutkimuksen kohteena', in Historiallinen Aikakauskirja, 2, pp. I 3 I-7

Heidle, Alexandre, and Jan Snoek, 2008. Women's Agency and Rituals in Mixed and Female Masonic Orders (Leiden \& Boston, Brill)

Johnson, Bruce, 20 I r. 'Introduction', in They Do Things Differently There: Essays on 
Cultural History, eds. Bruce Johnson and Harri Kiiskinen, cultural history kulttuurihistoria 9 (Turku, k\&h-kustannus), pp. I-I 8

Kaartinen, Marjo, 201 8. 'Vera Hjelt and the calling of theosophical universal work, I 894-1 904', Approaching Religion, 8( I), pp. I7-30, doi: <https://doi. org/I0.30664/ar.66735>

Kokkinen, Nina, 20 I 9. Totuudenetsijät. Vuosisadanvaibteen okkulttuuri ja moderni henkisyys Akseli Gallen-Kallelan, Pekka Halosen ja Hugo Simbergin taiteessa, Turun yliopiston julkaisuja, Scripta Lingua Fennica Edita, 469 (Turku, Turun yliopisto), <http://urn.fi/URN:ISBN:978-95 I-29-7607-2>

Kokkinen, Nina, and Tiina Mahlamäki, 2020. 'Näkökulmia esoteerisuuteen ja okkultismiin', in Moderni esoteerisuus ja okkultismi Suomessa, eds. Tiina Mahlamäki and Nina Kokkinen (Tampere, Vastapaino), pp. I I-29

Kortelainen, Anna, 2006. Naisen tie. L. Onervan kapina (Helsinki, Otava)

Kouta, Aarni, I 9 I r. Jäiset temppelit. Runoja (Helsinki, Yrjö Weilin)

Kraft, Siv Ellen, 2013. 'Theosophy, gender and the "new woman", in Handbook of the Theosophical Current, eds. Olav Hammer and Mikael Rothstein (Leiden and Boston, Brill), pp. 357-74

Laine, Johannes, and Nina Kokkinen, 2020. 'Ruusuristiläisyys ja Pekka Ervastin perintö', in Moderni esoteerisuus ja okkultismi Suomessa, eds. Tiina Mahlamäki and Nina Kokkinen (Tampere, Vastapaino), pp. I I 3-3 I

Lejeune, Philippe, 2009. On Diary, eds. Jeremy D. Popkin and Julie Rak, transl. Katherine Dunin (Honolulu, The University of Hawai' $i$ Press)

Lepore, Jill, 20 I 3. Book of Ages. Life and Opinions of Jane Franklin (New York, Knopf) Leskelä-Kärki, Maarit, 2006. Kirjoittaen maailmassa. Krohnin sisaret ja kirjallinen elämä (Helsinki, SKS)

_ 20 I 4. 'Suhteellista elämää. Relationaalisuus ja biografinen vuorovaikutus,' in Historiallinen elämä. Biografia ja historiantutkimus, eds. Heini Hakosalo, Seija Jalagin, Marianne Junila and Heidi Kurvinen (Helsinki, SKS), pp. 3 I 4-30

2016. 'Remembering mother: biographical project on Minna Krohn (I 84I-I 9I 7)', in Biography, Gender and History: Nordic Perspectives, eds. Erla Hulda Halldórsdottir, Tiina Kinnunen, Maarit Leskelä-Kärki and Birgitte Possing (Turku, k\&h-kustannus), pp. I 87-209

20I 7. Toisten elämät. Kirjoituksia elämäkerroista (Helsinki, Avain)

Mahlamäki, Tiina, 20 I 7. Kaikki maallinen on vain vertauskuvaa. Kirjailija Kersti Bergrotbin elämäkerta (Helsinki, Partuuna)

Mahlamäki, Tiina, and Maarit Leskelä-Kärki, 20 I 8. 'The history of modern Western esotericism: individuals, ideas, practices', in Approaching Religion, 8(I), pp. I-4, doi: <https://doi.org/I0.30664/ar.70 I 94>

Mahlamäki, Tiina, and Nina Kokkinen (eds.), 2020. Moderni esoteerisuus ja okkultismi Suomessa (Tampere, Vastapaino)

Owen, Alex, I989. The Darkened Room: Women, Power, and Spiritualism in Late Victorian England (The University of Chicago Press) 
2004. The Place of Enchantment: British Occultism and the Culture of the Modern (The University of Chicago Press)

Pasi, Marco, 20 I 4. Aleister Crowley and the Temptation of Politics (London, Routledge)

Possing, Birgitte, 201 7: Understanding Biographies: On Biographies in History and Stories in Biography (Odense, University Press of Southern Denmark)

Rajala, Panu, 20 18. Virvatuli. Eino Leinon elämä (Helsinki, WSOY)

Salmi, Hannu, 20 Iо. 'Kulttuurihistoria, mahdollinen ja runsauden periaate', in Kulttuuribistoriallinen katse, eds. Heli Rantala and Sakari Ollitervo, cultural history - kulttuurihistoria (Turku, k\&h-kustannus), pp. 338-59

Sarjala, Jukka, 2o I 4. 'Päättymätön yksilö. Henkilöhistorian muuntuva kohde', Ennen Eं Nyt, 6, <http://www.ennenjanyt.net/20 I 4/o6/paattymatonyksilo-henkilohistorian-muuntuva-kohde-2/> (accessed I 9.3.2020)

Seekers of the New, project website, <https://uudenetsijat.com/english/> Tarkka, Pekka, 2009. Joel Lehtonen. Vuodet 1881-1917 (Helsinki, Otava)

Ylikangas, Mikko, 2009. Unileipää, kuolonvettä, spiidiä. Huumeet Suomessa 18001950 (Jyväskylä, Atena) 